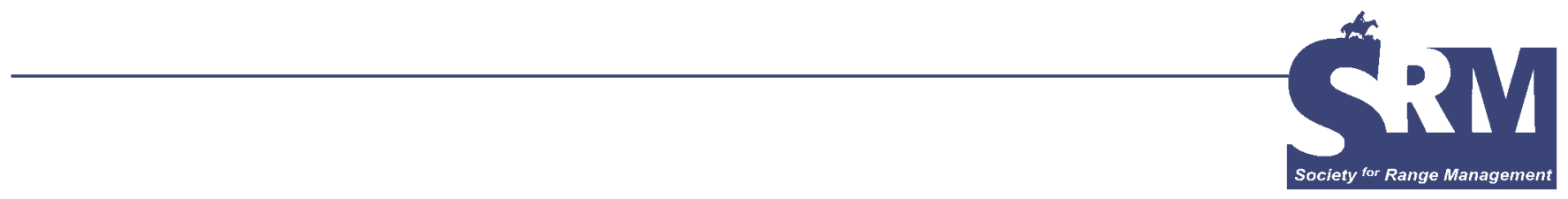

\title{
Nara Desert, Sindh, Pakistan: Part III: Range Types and Their Plant Resources
}

\section{By Rahmatullah Qureshi and G. Raza Bhatti}

\section{Introduction}

Nara Desert, the northern part of Thar Desert (Fig. 1), is characterized by high wind velocity, massive shifting and rolling sand dunes, high diurnal variation of temperature, scanty rainfall, extreme solar radiation, and high rates of evapotranspiration. It receives between $88-135 \mathrm{~mm}$ of rainfall every year, mostly between July and September. The sandy soils of the desert have a rapid infiltration rate of water, poor fertility, low organic matter due to hasty oxidation, and high salinity. All these conditions are very hostile for the existence of life, although large human and livestock populations inhabit the area. This desert is highly fragile with poor primary producer but large responsibility (ie, the consumers cause severe obstruction in its ecological regeneration).

The word desert gives the notion of a vast, lifeless, undulating area of sand. The Nara region does not concur with this popular conception. It is not a perpetual elongation of sand dunes devoid of life or vegetation. During the rainy season, it blooms with a colorful range of trees and grasses. It transforms into lush green with the slightest amount of precipitation because the soil is full of dormant seeds of various species, which germinate with little moisture.

\section{Vegetation}

The vegetation in the Nara Desert region is sparse, consisting mainly of stunted, thorny, or prickly shrubs and perennial herbs capable of drought resistance. Trees are few and scattered. The ephemerals come up during the rainy season, completing their life cycle before the advent of summer, and the bulk of the area is once more transformed into an open,

This article has been peer reviewed. sandy plain that is desolate and barren. Four types of plant groups were observed in this area and are described below on the basis of their growth and habitats performance: ${ }^{1}$

\section{True Xerophytes}

- Succulence.

- Covered with trichomes.

- Reduce the size and length of transpiring parts (ie, leaves), leaflessness, etc. Includes Haloxylon stocksii, Arthrocnemum indicum, Saueda fruticosa, Salsola imbricata, Aerva spp., and Glinus lotoides.

\section{Semi-xerophytes}

- Plants which grow in arid climate in the presence of sufficient amount of precipitation. Includes Acacia nilotica, Calotropis procera, Heliotropium europium, $H$. currasavicum, and Withania somnifera. These plants grow mostly on the periphery of the desert.

3. Pseudo-xerophytes

- Ephemerals which complete their life cycle within 6-8 weeks before the advent of summer. Includes Neurada procumbense, Mollugo spp., Gisekia pharancoides, Cleome brachycarpa, Boerhavia procumbense, and grasses like Eragrostis minor, Stipagrostis plumosa, and Aristida spp.

\section{Hydrophytes}

- Plants which live in water or in very moist habitat. Includes Cyperus rotundus, Fimbristylis dichotoma, Phragmites karka, Saccharum bengalense, and Typha spp.

\section{Range Types and Their Plant Resources}

During a survey from 1998-2001, 5 distinct range types were constructed from the Nara Desert, Pakistan, based on topographical features and plant resources. ${ }^{2}$ In addition, a sixth 


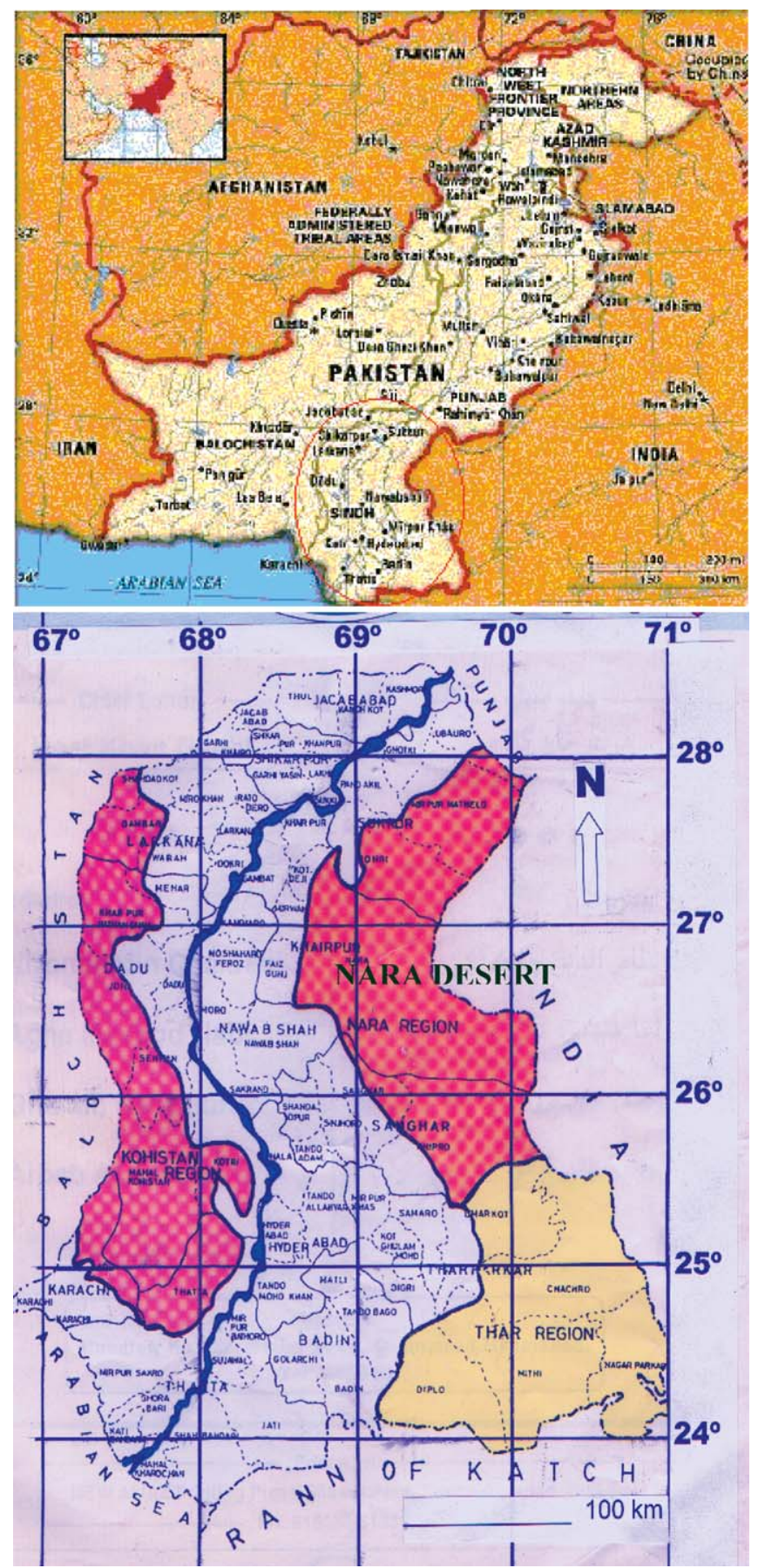

Figure 1. Map of Pakistan showing the location of the Nara Desert.

type (Hilly Tract) was also identified ${ }^{1}$ and will be discussed in a separate paper.

A total of 145 species belonging to 101 genera and 41 families were recorded during the report period. Species composition in the different range types showed differences in species richness. The highest species richness of $72 \%$ is recorded from flat range type. Crest range possessed fewer species as compared to the rest of the range types. The vegetation over this major area is characterized by xerophytic adaptation. The most common plants in this desert are Cal-

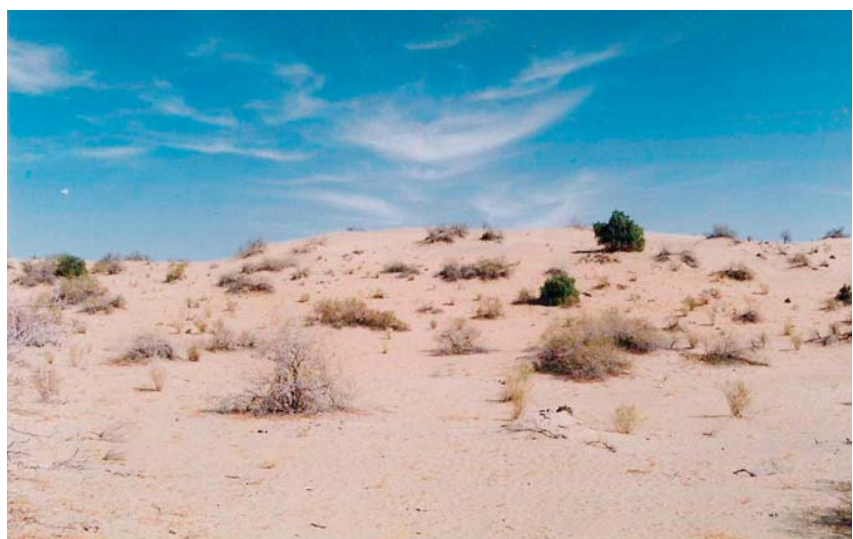

A view of crest range showing sparse vegetation.

ligonum polygonoides (Phog), Aerva javanica (Booh), Dipterygium glaucum (Phair), Crotalaria burbia (Chagg), Prosopis cineraria (Kandi), Tamarix aphylla (Lao), Capparis decidua (Kirar), Salvadora oleoides (Jaar), Leptadenia pyrotechnica (Khipp), Aristida spp. (Lumb Gaah), Limeum indicum (Dhoor Chhapri), and Stipagrostis plumosa (Lumb Gaah) growing in crest, slope and flat range types. Saline/sodic land and wetland ranges possess halophytic and hydrophytic characteristic features.

\section{Crest Range}

Sand dunes comprise the main characteristic features of the study area. Topography of this range varies from undulating to moderately steep with elevation from 70-120 m. These sand dunes are very excessively drained. Most of the area is barren and only 18 plant species ( $12 \%$ of the total flora of the Nara Desert) are recorded from this range type. These plants can be regarded as sand-loving and have specialized adaptation for survival on sand dunes. The composition of the plant community of this range includes Calligonum polygonoides, Aerva javanica, Dipterygium glaucum, Limeum indicum, Indigofera argentea, Tribulus longipetalus, Aristida adscensionis, A. funiculata, Panicum turgidum, Lasiurus sindicus, Stipagrostis plumosa, Cyperus arenarius, and C. conglomeratus.

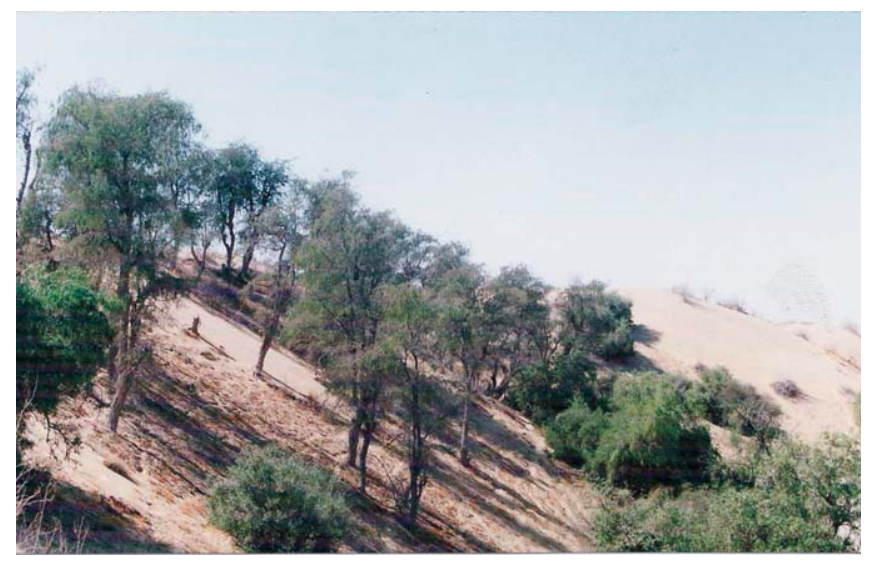

Slope range showing mixed vegetation of trees and shrubs. 


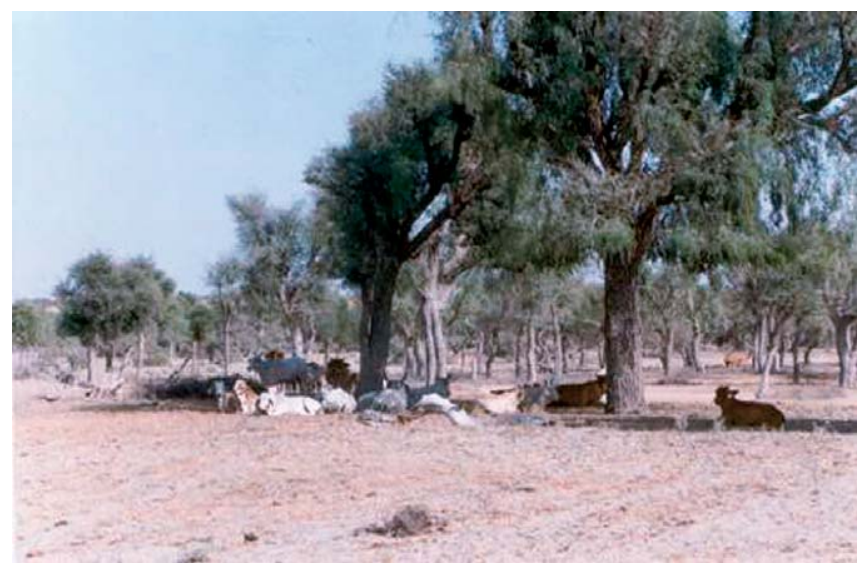

Flat habitat showing thick pockets of trees of Tamarix aphylla and Prosopis cineraria.

\section{Slopes/Swale/Flank Range}

This range type supports plant species similar to those supported by the crest range. A total of 32 species $(22 \%$ of the total flora of the Nara Desert) were recorded from this range, including a few trees like Prosopis cineraria, Tamarix aphylla, Salvadora oleoides, and Capparis decidua. The common plants that form the typical vegetation type of this range type are Calligonum polygonoides, Aerva javanica, Dipterygium glaucum, Limeum indicum, Indigofera argentea, Tribulus longipetalus, Aristida adscensionis, A. funiculata, Panicum turgidum, Lasiurus sindicus, Stipagrostis plumosa, Cyperus arenairus, and $C$. conglomeratus.

\section{Sandy Plains Range (Tar-Tarail Low-lying Flat Area)}

The sandy plains range occurs in low-lying flat areas between sand dunes. This range type supports a mixed population of tall and old trees of Prosopis cineraria, Tamarix aphylla, and Capparis decidua presenting a forested look. The highest diversity of species was recorded from this range with 105 species (72\% of the total flora of the Nara Desert). The most common plant species included Aerva javanica, Aristida adscensionis, A. funiculata, Boerbavia procumbense, Calligonum polygonoides, Capparis decidua, Cassia italica, Cenchrus ciliaris, Cleome brachycarpa, C. scaposa, Corchorus depressus, Cymbopogon jawarancusa, Cynodon dactylon, Cyperus rotundus, Dactyloctenium aegyptium, Heliotropium strigosum, Limeum indicum, Polygala erioptera, Salsola imbricata, Stipagrostis plumosa, Tephrosia uniflora, Tribulus longipetalus, and Zaleya pentandra. Trees are very commonly observed in this range forming a mini-forest. These include Prosopis cineraria, Tamarix aphylla, Capparis decidua, and Salvadora oleoides.

\section{Saline/Sodic Land (Kharror)}

This range is found between interdunal areas of the desert. It was formed by evaporation of saltwater in the lakes leaving behind high residual salt concentrations. These salty lands, locally called Kharror, occupy the edges of saline lakes. A total of 24 plant species ( $17 \%$ of the total flora of the Nara Desert)

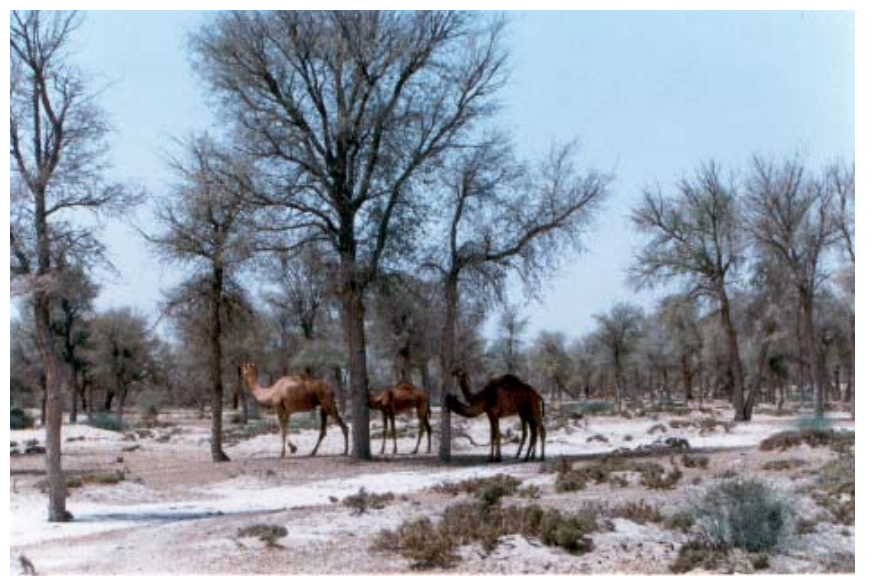

Saline sodic land range showing stunted vegetation.

are recorded from this range. The most common plants of this range are Tamarix indica, Saccharum spontaneum, Salsola imbricata, Pluchea lanceolata, Prosopis cineraria, Limeum indicum, Aeluropus lagopoides, Desmostachya bipinnata, and Alhagi maurorum.

\section{Lake/Wetland Range}

Seepage has created wetlands on both banks of the Nara Canal. The extent of the wetland (locally called Dhand) solely depends upon the water availability in the Nara Canal. ${ }^{3}$ Nearly 40 lakes are observed in the study area. There were 17 species (12\% of the total flora of the Nara Desert) growing in this range type. The edges of lakes are dominated by undestroyed plant communities consisting of common species in this range like Saccharum bengalense, S. spontaneum, and Tamarix passernioides. Aeluropus lagopoides, Cynodon dactylon, Desmostachya bipinnata, and Phragmites karka are also common species in this range. These plants typify emergent vegetation, which has its roots in soil covered or saturated with water and its leaves held above water.

\section{Conclusion}

Dune lands and slopes are dominated by the tussock grasses Panicum turgidum and Lasiurus sindicus. These species were

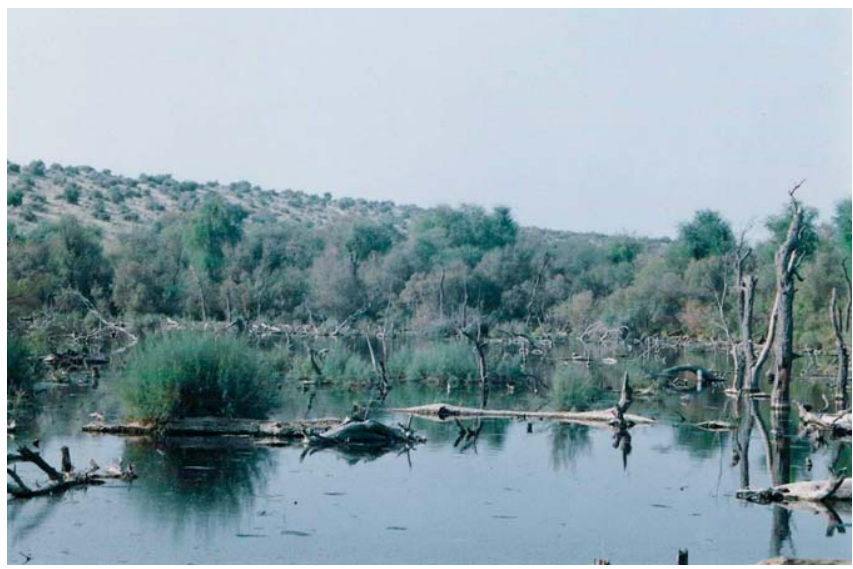

Wetland range having halophytic vegetation. 
grazed by flocks of goats, cows, and camels at medium to high rates of utilization in the early wet, late wet, or dry seasons. Effects of grazing on species composition were greatest in the early wet season. Therefore, the range types of the Nara Desert are under immense pressure and need conservation. Moreover, range management programs should be launched to maintain the continuity of plant and human life.

Plants are the only source enriching the rangeland in the shape of pasture. Besides supplying food for livestock, there are other uses of plants, including turf, fuel, human nutrition, and medicine. ${ }^{1}$ The genetic diversity of range and forage grasses, legumes, and other forbs needs to be preserved. These plants are capable of triumphing over restrictions to their growth and development, producing high-quality forage, and serving a variety of conservation and other uses. Therefore, managed livestock grazing is very essential for the sustainable use of rangeland and pasture resources.

Authors are Seed Certification Officer for the Federal Seed Certification $\mathcal{E}^{2}$ Registration Department, Government of Pakistan
Rahim Yar Khan, Punjab, Pakistan, deserttaxonomist@yahoo. com (Qureshi); and Professor, Shah Abdul Latif University, Khairpur, Sindh, Pakistan (Bhatti). At the time of research, the senior author was a Research Associate in the Department of Botany, Shah Abdul Latif University, Khairpur, Pakistan. This work was carried out under the research project entitled "Floristic Study of Arid Zone (Desert-Nara Region), Sindh, Pakistan" SSALU/ENVR (45) sponsored by Pakistan Science Foundation, Islamabad, which is thankfully acknowledged.

\section{References}

1. Qureshi, R. 2004. Floristic and ethnobotanical study of Desert-Nara Region, Sindh [dissertation]. Khairpur, Pakistan: Shah Abdul Latif University. 289 p.

2. Bhatti, G. R., M. Shah, and R. Qureshi. 2001. Floristic study of arid zone (Desert-Nara Region). Sindh, Pakistan: Department of Botany, Shah Abdul Latif University Khairpur, Pakistan. Final Technical Report S-SALU/ENVR (45). 190 p.

3. Qureshi, R., and G. R. Bhatti. 2005. Nara Desert, Pakistan: part II: human life. Rangelands 27(5):32-35.

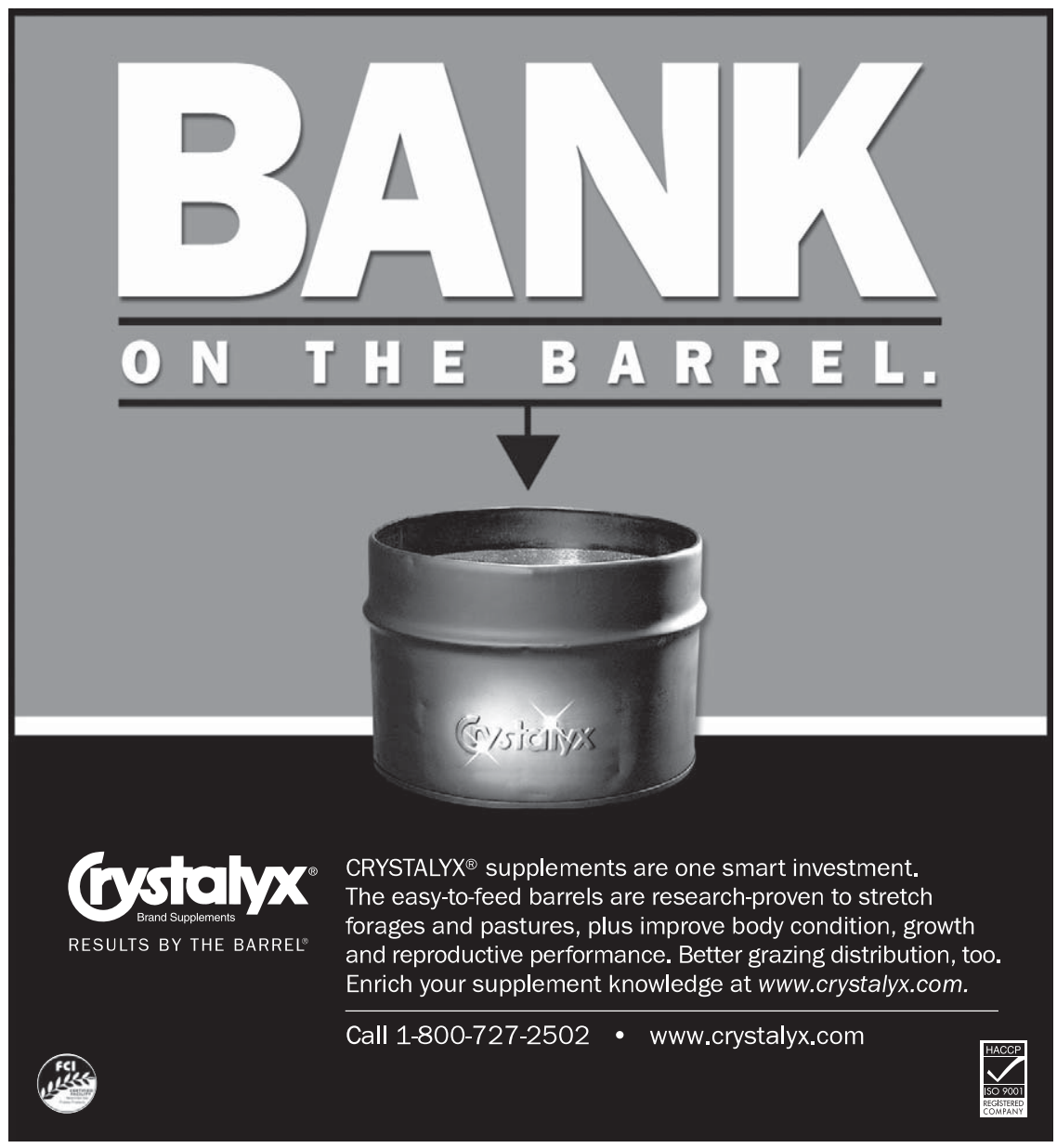

